\title{
Effect on the bactericidal device for decontamination the air microorganisms in poultry house on the content of toxic gases
}

\author{
A.P. Palii ${ }^{1}$, O.V. Nanka ${ }^{1}$, Y.O. Kovalchuk ${ }^{2}$, A.O. Kovalchuk ${ }^{3}$, V.S. Kalabska ${ }^{4}$, I.V. Kholod ${ }^{4}$, \\ O.M. Pobirchenko ${ }^{4}$, O.S. Umrihina ${ }^{4}$, A.M. Poliakov ${ }^{5}$, K.V. Ishchenko ${ }^{1}$, A.P. Paliy* 6 \\ ${ }^{1}$ Kharkiv National Technical University of Agriculture named after Petro Vasylenko, \\ Str. Alchevskih, 44, Kharkiv, 61002, Ukraine. \\ ${ }^{2}$ Uman National University of Horticulture, \\ Prov. Internatsionalniy, 1, Uman, Cherkasy region, 20305, Ukraine. \\ ${ }^{3}$ Ivan Kozhedub Kharkiv National Air Force University, \\ Str. Sumska, 77/79, Kharkiv, 61023, Ukraine. \\ ${ }^{4}$ Pavlo Tychyna Uman State Pedagogical University, \\ Str. Sadova, 2, Uman, Cherkassy region, 20300, Ukraine. \\ ${ }^{5}$ Luhansk National Agrarian University, \\ Str. Slobozhanska, 68, Starobelsk, 92703, Ukraine. \\ ${ }^{6}$ National Scientific Center «Institute of Experimental and Clinical Veterinary Medicine», \\ Str. Pushkinska, 83, Kharkiv, 61023, Ukraine. \\ *Corresponding author E-mail: paliy.andriy@ukr.net
}

\section{Received: 15.12.2019. Accepted 20.01.2020}

\begin{abstract}
Litter in the poultry house is a source of toxic gases (ammonia, hydrogen sulphide and carbon dioxide), dust, and is a favourable place for the life and reproduction of microorganisms and helminths. The number of these secretions in the poultry house depends on many factors: the sanitary status of the poultry house, the species, the age of the birds, the microclimate, the season, feeding conditions, and so on. The purpose of the research was to substantiate the rational construction and modes of operation of the device for the decontamination of microorganisms in the air of the poultry house on the basis of the use of sources of ultraviolet irradiation. The necessity of development and application techniques for cage batteries with a litter removal belt system which provide reduction of microbial contamination of air in poultry houses and the content of harmful gases in it have been substantiated. The device was developed and the effective mode of disinfection of the air of the poultry house in the collector air duct of the litter drying system based on the use of sources of ultraviolet irradiation was determined. The application of the bactericidal device made it possible to reduce microbial air contamination on the $1^{\text {st }}$ day of accumulation of the litter during the cold season - by 2.6 times, in the transitional season - by 2.1 times; on $5^{\text {th }}$ day, the accumulation of the litter decreased by 3.0 and 2.3 times, respectively. During the operation of the air irradiation system, the content of toxic gases in it decreased compared to the period when the air was not treated with the ultraviolet irradiation - ammonia by $19.7 \%$ and carbon dioxide by $5.9 \%$. The absolute values of microbial air contamination in the poultry house and the toxic gas content in the transitional season were lower than in the cold season, due to the higher indoor air exchange and the increase of clean outside air in the proportion. The difference in microbial air contamination between the basic and the proposed variants in the cold and transitional seasons was statistically significant.
\end{abstract}

Key words: Poultry house; Microclimate; Air; Bacterial contamination; Toxic gases; Ultraviolet irradiation

\section{Introduction}

In industrial poultry farming, maintaining poultry health, improving its productivity, and obtaining quality products have always remained the most important tasks. Keeping the poultry on the farms is associated with its complete isolation from its natural habitat. Therefore, there is a need to create optimal conditions for poultry to maintain their health and increase productivity.

However, some poultry farms continue to use the same premises and restrict sanitation. This leads to an increase in the contamination of the premises with opportunistic and pathogenic microflora, the composition and diversity of which change regularly. It has been found that high bacterial contamination of the air environment may contribute to the initiation of infections (Mpundu et al., 2019). The interaction of the bird's organism with not one but a number of microorganisms of different taxonomic groups leads to a stressful state. Thus, with long-term effects of one or more of these stressors, general and specific resistance decreases, and the likelihood of the affection of the bird with various infections, such as colibacteriosis, tuberculosis, salmonellosis, pasteurellosis, etc., occurs. (Essam et al., 2018; Paliy et al., 2018a). An increase in the total number of microorganisms, including opportunistic bacteria in the air and on structures, is observed in rooms that do not adhere to the 'empty-occupied' zoohygienic principles and which are not subject to disinfection for a long time (Milanov et al., 2017; Paliy et al., 2018b). In the premises of different farms, the level of microbial contamination may vary depending on climatic factors, housing conditions, technological processes, etc. (Oakley et al., 2013). 
Excessive concentrations of ammonia and hydrogen sulphide in the premises reduce the safety and productive performance of the poultry and adversely affect the health of service staff (Ishchenko et al., 2019). Also, a high concentration of ammonia in the poultry house results in various diseases of the bird's respiratory system, pathological changes in the trachea, lungs, kidneys and liver (Naseem \& King, 2018). In addition, increased ammonia levels have been shown to cause keratoconjunctivitis, reduce body weight, and impair feed conversion (Rouger et al., 2017). According to other data (Muir et al., 2014), an increase in ammonia levels causes weakness of the capillary walls, a decrease in macrophage function, an increase in sensitivity to respiratory diseases, a decrease in the ability of the bird to remove $E$. coli from the lungs and air sacs. Increased microbial contamination of poultry houses and toxic gas content contributes to high bacterial contamination not only of the birds' organisms but also of poultry production, which reduces its quality and can cause disease in humans (including colibacteriosis and salmonellosis) (Paliy et al., 2018c; Tan et al., 2019; Zhao et al., 2015). Som eauthors (Broucek \& Bohuslav, 2015; Palii et al., 2019; Potter et al., 2012) developed a number of techniques aimed at reducing the microbial contamination of air in the poultry houses and harmful gases content in the air. However, these techniques mainly concern keeping the poultry on the litter bedding. The development of safe and cost-effective techniques for reducing microbial air contamination and the toxic gases content in the air when using cage batteries equipment, in particular - with litter removal belt system, remains an unsolved task. Therefore, the study of microbial contamination and its impact on the body of the bird, the development of ways to reduce the bacterial background and the content of toxic gases on poultry farms are urgent problems in increasing production efficiency and improving the quality of poultry products. This explains the increased interest of scientists in the study of means and methods of optimizing the microbiological contamination of the air environment of poultry houses.

\section{Materials and Methods}

The purpose of the research was to substantiate the rational design and modes of operation of the device for the disposal of microorganisms in the air of the poultry house based on the use of sources of ultraviolet radiation. The study was carried out in the poultry house, $18 \times 96 \mathrm{~m}$ in size, with a capacity of 47280 egg laying hens. The poultry was kept in 4-tier 'Hellmann' cage batteries (Germany) equipped with a litter removal belt system and build-in air ducts. To neutralize the microorganisms it was proposed to use bactericidal lamps with a wavelength of ultraviolet irradiation of $253.7 \mathrm{~nm}$, placed at the main air ducts, through which the air from the mixers of the litter drying system is fed into the ducts installed above the litter removal belt conveyors. The diameter of the duct was $1 \mathrm{~m}$. Philips TUV TL-D 75W HO SLV bactericidal lamps, $75 \mathrm{~kW}$, in quantities of 6, 12 and 24 pieces, were installed inside the duct perimeter wind of its inner circle in one ( 6 and 12 pcs.) and 2 rows ( 24 pcs.) along the duct. Main specifications of TUV TL-D 75W HO SLV lamps are given in Table 1.

Table 1. The main technical characteristics of the bactericidal lamp TUV TL-D 75W HO SLV.

\section{Name of indicators}

Electric power of the lamp, W

Supply voltage, $\mathrm{V}$

Current through the lamp, A

Bactericidal flux, $\mathrm{W}$

Useful life, $h$

Shape of the bulb

Type of the lamp cap

Diameter of the bulb, $\mathrm{mm}$

Mass, $\mathrm{g}$

Length without contact pins, $\mathrm{mm}$

\section{Value of indicators}
75
108
0.84
25.5
8000
T26
$\mathrm{G} 13$
28
186
1199.4

The total bactericidal flux was: when using 6 lamps - $153 \mathrm{~W}$ (volumetric dose of ultraviolet irradiation $15 \mathrm{~J} / \mathrm{m}^{3}$ ), 12 lamps - $306 \mathrm{~W}$ (volumetric dose of ultraviolet irradiation $-30 \mathrm{~J} / \mathrm{m}^{3}$ ), 24 lamps $-612 \mathrm{~W}$ (volumetric dose of ultraviolet irradiation - $60 \mathrm{~J} / \mathrm{m}^{3}$ ). The amount of air supplied by the duct averaged $30.000 \mathrm{~m}^{3} / \mathrm{h}$. Schematic diagram of the bactericidal device is shown in Figure 1 .

The total microbial contamination of air and the toxic gases content in it were studied: before its irradiation (in the area of the air duct before bactericidal lamps) and after irradiation (in the area of the air duct after bactericidal lamps and in the duct installed above the litter removal conveyor) as well as in the poultry house, according to standard techniques. Each parameter was determined in the specified places in the amount of not less than 5 performed in triplicate in each of 3 variants. The total number of samples selected was 180 .

\section{Results and Discussion}

The following options were considered as possible variants of microbial disinfection in the air of the poultry house: 1 - air disinfection immediately in the poultry house, 2 - disinfection of the air of the poultry house, which was sent for recirculation, in the air mixer chamber. In the case, when cage batteries with built-in air ducts are used, the latter variant of disinfection was considered as more acceptable (cheaper and safer), since the need to reduce microbial air pollution was mainly in the cold season, and according to preliminary calculations, a significant reduction in microbial air pollution sent for recirculation, providing a reduction of microbial air pollution in general in the poultry house to a level below the maximum permissible concentrations (MPC). 


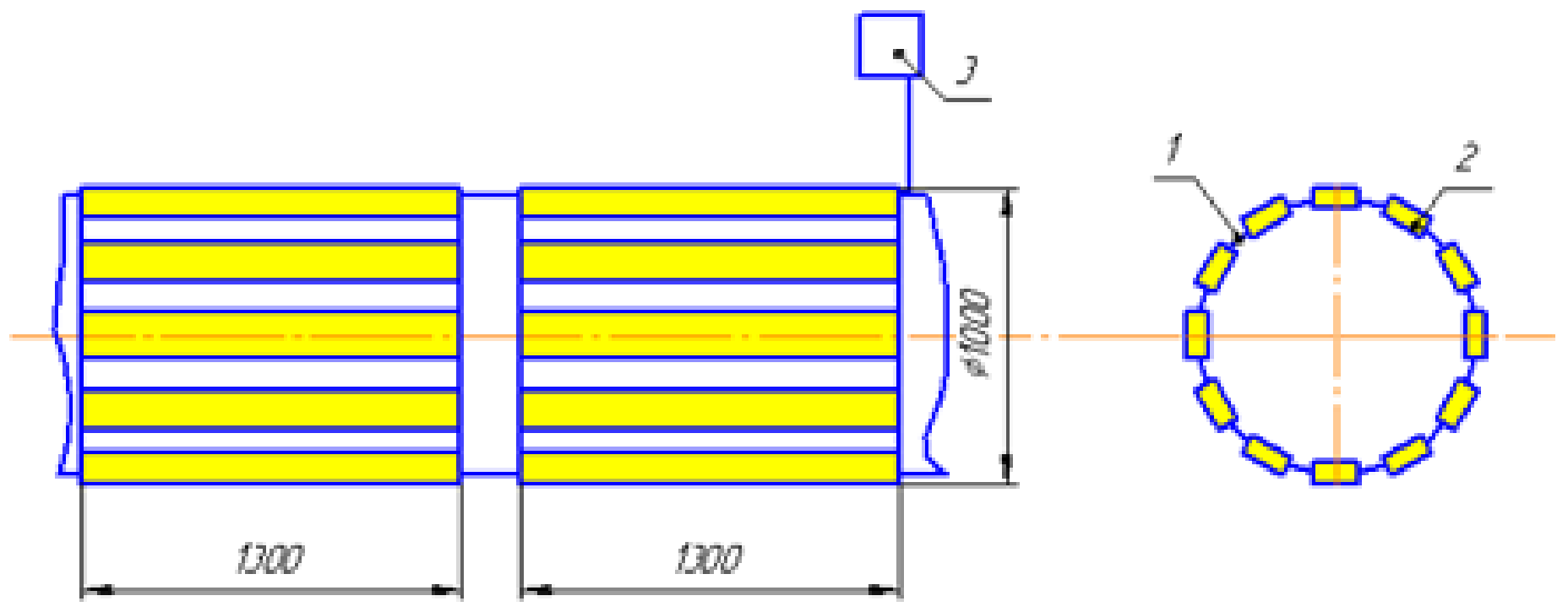

Figure 1. Layout scheme of the bactericidal device in the collector duct of the litter drying system: 1 - collector duct; 2 - TUV TL-D 75W HO SLV bactericidal lamps; 3 - block of automatic control of bactericidal lamps.

The main methods of decontamination of microorganisms in the air have been analysed: the $1^{\text {st }}$ - by exposure to disinfectants (wet or aerosol methods), the $2^{\text {nd }}$ - by ozone, and the $3^{\text {rd }}$ - by ultraviolet radiation (UVR). The latter method was found to be the most suitable for use in the mixer chamber by a number of indicators: ease of construction and maintenance, reliability of the equipment used, sufficient bactericidal efficiency and safety in use, the expected additional effect of reducing the toxic gases concentration.

According to normative documents (ВНТП-АПК-04.05, 2005): 'Departmental Technological Design Standards for Agro-Industrial Complex. Poultry Enterprises' and 'Sanitary Processing Instructions - Disinfection, Pest Control and Deratization of Poultry Objects' (Order No. 69 dated 20.06.2007), if it is necessary to decontaminate $99.0 \%$ of microorganisms in the air, the volumetric dose of ultraviolet irradiation should be $256 \mathrm{~J} / \mathrm{m}^{3}, 95 \%-167 \mathrm{~J} / \mathrm{m}^{3}, 80 \%-90 \mathrm{~J} / \mathrm{m}^{3}$. When calculating the bactericidal plant for the poultry house, in view of the requirement that the microbial contamination of the air in the premise is to be reduced to a level below the MPC ( 220 thous. microbial units $/ \mathrm{m}^{3}$ of the air), for which it was necessary to provide at least $50 \%$ level of microbial decontamination.

Three variants of the bactericidal plant layout were developed based on the use of Philips $75 \mathrm{~W}$ TUV-75 bactericidal lamps. The first and second layout variants included the installation of a collector duct along the perimeter of the intake manifold, through which the air from the mixer is fed to the ducts placed on the litter removal conveyor, with 6 and 12 TUV-75 bactericidal lamps, respectively. The third variant provided for the installation of 24 the same lamps in the collector duct, but in two consecutive rows.

The results of studies of the effectiveness of microbial disinfection in the air of the poultry hose, depending on the number and method of placement of bactericidal lamps are given in Table 2.

According to the study, before the bactericidal lamps were switched on, the microbial contamination of the air in the poultry house was 624-651 thous. microbial units per $1 \mathrm{~m}^{3}$, which is 2.8-3.0 times higher than the MPC. The microbial contamination of the air in the collector duct before the bactericidal lamps was less than in the poultry house due to mixing with clean outside air. The irradiation of the air in the collector duct made it possible to reduce its microbial contamination, when passing by the bactericidal lamps, by 1.16 times - in the $1^{\text {st }}$ layout variant, 1.6 times - in the $2^{\text {nd }}$ variant and 2.7 times - in the $3^{\text {rd }}$ layout variant.

Table 2. Microbial contamination of the air in the measurement point, depending on the number of bactericidal lamps and methods of their placement in the duct, thous. units per $\mathrm{m}^{3}$.

\section{Measurement point of microbial contamination of the air}

In the poultry house, before turning bactericidal lamps on

In the air ducts, before bactericidal lamps during their operation

In the air ducts immediately after bactericidal lamps during their operation

In the air ducts above the litter removal belt conveyor, during the operation of bactericidal lamps

In the poultry house, during the operation of bactericidal lamps Note: $* * *-\mathrm{P}<0.001$ (compared to the contamination level before turning bactericidal lamps on).

\section{Number of bactericidal lamps and method of their}

$624 \pm 39.3$

$243.3 \pm 17.8$

$209.7 \pm 19.6$

$182.4 \pm 18.7$

$517.1 \pm 31.7 * * *$

\section{6 lamps $1^{\text {st }}$ variant \\ placement \\ 12 lamps \\ $2^{\text {nd }}$ variant}

$638 \pm 24.8$

$194.5 \pm 16.1$

$124.7 \pm 12.3$

$91.8 \pm 7.8$
$25.9 \pm 2.3$

24 lamps

$651 \pm 27.8$

$99.4 \pm 5.2$

$36.2 \pm 3.7$
When passing through the manifold system, the microbial contamination of the air somewhat declined, probably due to the action of ozone produced by the use of bactericidal lamps. As a result, microbial air contamination in the poultry house decreased by 1.2 times when using 6 bactericidal lamps, by 1.7 times - when using 12 bactericidal lamps and by 3.3 times - when using 24 bactericidal lamps. In the latter case, microbial air pollution was below the MPC. The difference between microbial air contamination in the poultry house 
before switching on bactericidal lamps and during their operation, as well as between the variants of bactericidal lamps layout by this indicator was statistically significant $(P<0.001)$. The treatment of inflowing air with ultraviolet irradiation also affected the toxic gas content in it (Table 3).

Table 3. Influence of air disinfection with the ultraviolet irradiation on the toxic gases content in it.

\section{Measurement point of the toxic gases content}

In the poultry house, before turning bactericidal lamps on:

ammonia, $\mathrm{mg} / \mathrm{m}^{3}$

carbon dioxide, \%

hydrogen sulphide, $\mathrm{mg} / \mathrm{m}^{3}$

In the ducts, before bactericidal lamps during

their operation:

ammonia, $\mathrm{mg} / \mathrm{m}^{3}$

carbon dioxide, \%

hydrogen sulphide, $\mathrm{mg} / \mathrm{m}^{3}$

In the ducts above the litter removal belt conveyor during the operation of bactericidal lamps:

ammonia, $\mathrm{mg} / \mathrm{m}^{3}$

carbon dioxide, \%

hydrogen sulphide, $\mathrm{mg} / \mathrm{m}^{3}$

In the poultry house, during the operation of the bactericidal lamps:

ammonia, $\mathrm{mg} / \mathrm{m}^{3}$

carbon dioxide, \%

hydrogen sulphide, $\mathrm{mg} / \mathrm{m}^{3}$

\section{Number of bactericidal lamps and method of their placement}

6 lamps
$1^{\text {st }}$ variant

12 lamps

$2^{\text {nd }}$ variant

24 lamps

$3^{\text {rd }}$ variant
$17.4 \pm 0.54$
$17.8 \pm 0.47$
$17.1 \pm 0.39$
$0.16 \pm 0.0025$
$0.17 \pm 0.0041$
$0.18 \pm 0.0046$

$\begin{array}{ccc}7.2 \pm 0.59 & 6.6 \pm 0.62 & 5.2 \pm 0.071 \\ 0.08 \pm 0.0039 & 0.10 \pm 0.0061 & 0.09 \pm 0.0034\end{array}$

$\begin{array}{ccc}6.9 \pm 0.29 & 5.9 \pm 0.32 & 3.9 \pm 0.18 \\ 0.08 \pm 0.0024 & 0.09 \pm 0.0031 & 0.07 \pm 0.0026\end{array}$

Note: * $-\mathrm{P}<0.05 ; * * *-\mathrm{P}<0.001$ (compared to the level before turning bactericidal lamps on).

During the operation of the air irradiation system, the content of toxic gases in it decreased compared to the period when the air was not exposed to ultraviolet radiation: - $1^{\text {st }}$ variant of bactericidal lamps layout: ammonia by $4.0 \%$, no reduction of carbon dioxide content in the poultry house; - $2^{\text {nd }}$ variant of bactericidal lamps layout: ammonia by $8.4 \%$, reduction of carbon dioxide content in the poultry house was not recorded either; - $3^{\text {rd }}$ variant of bactericidal lamps layout: ammonia by $19.7 \%$, carbon dioxide by $5.9 \%$, but the difference in the content of carbon dioxide was not statistically significant. Based on these studies, the 3rd variant of bactericidal lamps layout was selected for the further work as the most effective one. During the production verification of the proposed device for the decontamination of microorganisms in the air of the poultry house on the basis of the use of UVR sources, a study was carried out, which predicted the accumulation of poultry litter on the belt conveyors of cage batteries (up to 5 days). This made possible to study different variations of the microbial contamination of the poultry house and to give an objective assessment of the operation of the device at different seasons. The microbial contamination of the air during the production inspection is shown in the Table 4.

Table 4. Microbial contamination of the air in the poultry houses (the basic and proposed variants) during the production inspection, thous. units per $1 \mathrm{~m}^{3}$.

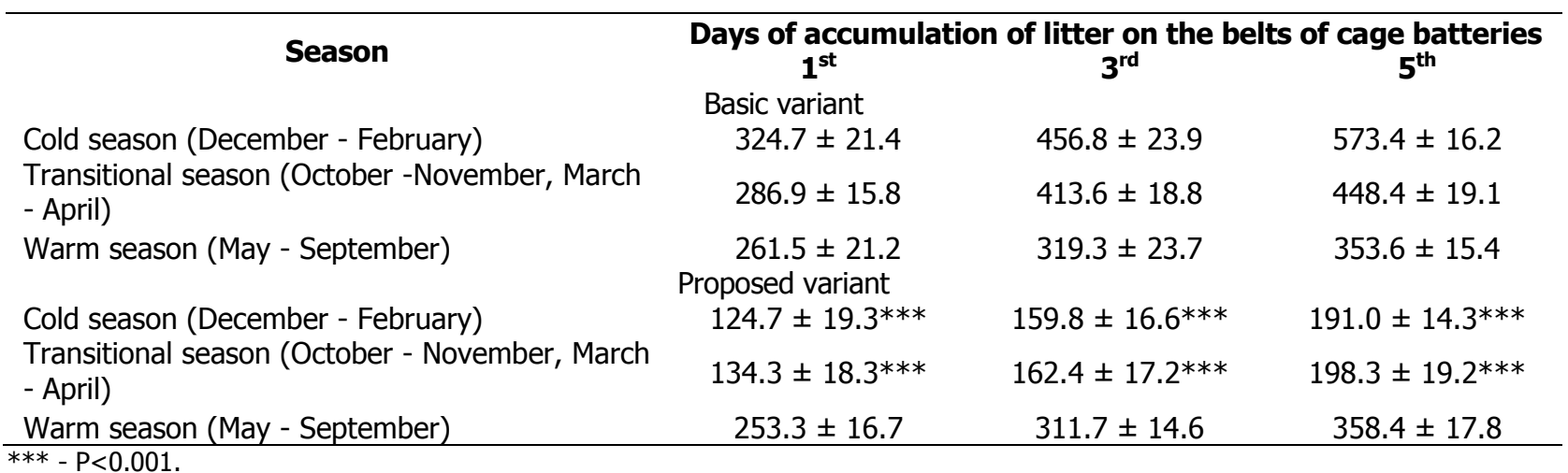
Note: ${ }^{* * *}-\mathrm{P}<0.001$

The use of the bactericidal device made it possible to reduce microbial contamination of air on the $1^{\text {st }}$ day of accumulation of litter in the cold season - by 2.6 times, in the transitional period of the year - by 2.1 times; on the $5^{\text {th }}$ day, the accumulation of litter it decreased by 3.0 and 2.3 times, respectively. In the experimental poultry house, during the cold and transitional season during the entire period of poultry rearing, the microbial air contamination was below the MPC. During the warm season, the bactericidal 
device was not used because the recirculation of air from the poultry house was not carried out, thus, the microbial contamination of the experimental and control poultry houses was similar and slightly above the MPC for cage rearing of the poultry, but it was below (up to 5 days after accumulation period) the MPC for floor rearing. Thus, the results of the production verification completely confirmed the effectiveness and practical significance of the proposed technological solution for the reduction of microbial air contamination in the poultry house and the toxic gases content in it. The works (Paliy et al., 2018d; Wells et al., 2010) prove that disease prevention works are an important part of the general technological process of functioning of any poultry farm.

The decrease in ammonia content due to the irradiation of the air with the ultraviolet radiation of the bactericidal range is also noted in the works by several other authors (Chidambaranathan \& Balasubramanium, 2017; Tahiru et al., 2019). This is explained, on the one hand, by the direct action of ultraviolet radiation on ammonia, on the other hand, by the ammonia is affected by ozone, which is formed in a certain amount from the oxygen of the air under the influence of ultraviolet radiation. As a result of the reaction of ozone with ammonia, ammonium nitrate is formed. The health of the poultry and its productivity largely depend on the sanitary well-being of the industrial area and the poultry house where it is kept. Thus, the research (Ishchenko, 2019) found that after 120-250 days of cage rearing of laying hens, from 48 to 450 and from 43 thous. to $1.9 \mathrm{mln}$. microorganisms per $1 \mathrm{~cm}^{2}$ on horizontal and vertical surfaces, respectively, were found. Along with saprophytic bacterial microflora and molds, enteropathogenic $E$. coli strains, salmonellae and several other microorganisms were picked out from many samples. The analysis of numerous data on the terms of preservation in the environment of opportunistic microorganisms indicates the need for careful sanitation of production zones of poultry farms (Milanov et al., 2017). One of the important constituents of the microclimate is the content of harmful gases (carbon dioxide, ammonia and hydrogen sulphide) that are accumulated as a result of the vital functions and decomposition of the litter. The intensity of gas exchange in birds is known to be much higher than that in animals. Improper aeration in the room causes the accumulation of a large amount of $\mathrm{CO}_{2}$, which leads to irritation of the mucous membranes, general weakness, lethargy and loss of appetite (Fernanda et al., 2017). Increased concentration of $\mathrm{NH}_{3}$ causes poisoning. Since ammonia reduces the oxidizing properties of haemoglobin, oxygen starvation and anaemia develop (Mendes et al., 2014).

Ammonia emission in the poultry house can be reduced by 'forage' methods'; for example, the normalization of protein and amino acids levels in the diet, introduction of various feed additives by technological methods, such as strict adherence to the normative parameters of the microclimate in the house, not exceeding the stock density parameters and reducing the litter bedding moisture, etc.; by physical methods - by means of ultraviolet irradiation of polluted air; by chemical methods - by adding different chemical reagents to the bedding or litter (Linlin et al., 2018; Naseem \& King, 2018). When studying the possibility of using UVR to purify the air from ammonia, the range of actual concentrations of ammonia in livestock premises was investigated. It has been found that ultraviolet radiation has a positive effect on reducing the concentration of ammonia. The longer the polluted air is exposed to UVR, the lower the final ammonia concentration. The reduction of ammonia to zero level is quite slow, but reducing it to levels below the maximum permissible concentration is quite fast. Researchers have concluded that this method can be used to purify the air from ammonia in livestock premises (Bilgili, 2006; Isohanni \& Lyhs, 2009; Waring \& Siegel, 2011). In the future, it is promising to study the microclimate in the poultry houses when various reagents are added to the litter, with the aim of reducing the presence of toxic gases in the air.

\section{Conclusion}

Application of the proposed technological method - irradiation of air in the litter drying system with an ultraviolet radiation (24 lamps - $612 \mathrm{~W}$ ) with a wavelength of $253.7 \mathrm{~nm}$ in a volume dose of $60 \mathrm{~J} / \mathrm{m}^{3}$ reduces the microbial contamination of air by 3.3 times - to a level below the maximum permissible concentration. During the operation of the air irradiation system, the toxic gases content in it decreased compared to the period when the ultraviolet irradiation of air was not carried out: ammonia by $19.7 \%$, carbon dioxide by $5.9 \%$, but the difference in the content of carbon dioxide was statistically insignificant. The results of the production verification confirmed the effectiveness and practical importance of the proposed technological solution for the reduction of microbial air contamination in the poultry house and the toxic gases content in it.

\section{References}

Bilgili, S. F. (2006). Sanitary/hygienic processing equipment design. World's Poultry Science Journal, 62(1), 115-122. doi: https://doi.org/10.1079/WPS200588

Broucek, J., \& Bohuslav, C. (2015). Emission of harmful gases from poultry farms and possibilities of their reduction. Ekológia (Bratislava), 34(1), 89-100. doi: https://doi.org/10.1515/eko-2015-0010

Chidambaranathan, A. S., \& Balasubramanium, M. (2017). Comprehensive review and comparison of the disinfection techniques currently available in the literature. Journal Prosthodont, 28(2), 849-856. doi: https://doi.org/10.1111/jopr.12597

Essam, S. Soliman, Nahla, H. Sallam, \& Eman, M. Abouelhassan. (2018). Effectiveness of poultry litter amendments on bacterial survival and Eimeria oocyst sporulation. Vet. World, 11(8), 1064-1073. doi:10.14202/vetworld.2018.1064-1073

Fernanda, C. S., Iida, F. F. T., Jagir, N. S., \& Baptista, F. J. F. (2017). Gas emission in the poultry production. Journal of Animal Behaviour and Biometeorology, 5(2), 49-55. doi: https://doi.org/10.14269/2318-1265/jabb.v5n2p49-55

Ishchenko, K. V. (2019). Investigation of the parameters of the microclimate of chickens and the chemical composition of the hens litter for the use of cell batteries with different air removal systems. Scientific and Technical Bulletin of IT NAAN, 121, 127-136. doi: https://doi.org/10.32900/2312-8402-2019-121-127-136

Ishchenko, K. V., Palii, A. P., Kis, V. M., Petrov, R. V., Nagorna, L. V., Dolbanosova, R. V., \& Paliy, A. P. (2019). Investigation of microclimate parameters for the content of toxic gases in poultry houses during air treatment in the scrubber with the use of various fillers. Ukrainian Journal of Ecology, 9(2), 74-80.

Isohanni, P. M., \& Lyhs, U. (2009). Use of ultraviolet irradiation to reduce Campylobacter jejuni on broiler meat. Poultry Science, 88, 661-668.

Jiang, L., Li, M., Tang, J., Zhao, X., Zhang, J., Zhu, H., ... Zhang, X. (2018). Effect of Different Disinfectants on Bacterial Aerosol Diversity in Poultry Houses. Frontiers in microbiology, 9, 2113. doi: https://doi.org/10.3389/fmicb.2018.02113

Mahami, T., Togby-Tetteh, W., Kottoh, D. I., Amoakoah-Twum, L., Gasu, E., Annan, S., ... Adu-Gyamfi, A. (2019). Microbial Food Safety Risk to Humans Associated with Poultry Feed: The Role of Irradiation. International journal of food science, $2019,6915736$. doi: https://doi.org/10.1155/2019/6915736

Mendes, L. B., Tinoco, I. F. F., Ogink, N., Osorio, R. H., \& Osorio, S. J. (2014). A refined protocol for calculating air flow rate of naturally-ventilated broiler barns based on CO2 mass balance. Revista DYNA, 81(1), 197-203. doi:10.1590/1807-1929/agriambi.v 
Milanov, D., Ljubojević, D., Cabarkapa, I., Karabasil, N., \& Velhner, M. (2017). Biofilm as risk factor for Salmonellacontamination in various stages of poultry production. Europ. Poultry Science, 81. doi:10.1399/eps.2017.190

Mpundu, P., Mbewe, A. R., Muma, J. B., Zgambo, J., \& Munyeme, M. (2019). Evaluation of Bacterial Contamination in Dressed Chickens in Lusaka Abattoirs. Front. Public Health, 7, 19. doi:10.3389/fpubh.2019.00019

Muir, W. M., Cheng, H. W., \& Croney, C. (2014). Methods to address poultry robustness and welfare issues through breeding and associated ethical considerations. In: Rauw W. M., editor. Improving Animal Welfare through Genetic Selection. Frontiers in Genetics, Lausanne, Switzerland, 407-420. doi:10.3389/fgene.2014.00407

Naseem, S., \& King, A. J. (2018). Ammonia production in poultry houses can affect health of humans, birds, and the environmenttechniques for its reduction during poultry production. Environ Science Poultry Res. Int., 25(16), 15269-15293. doi:10.1007/s11356018-2018-y

Oakley, B. B., Morales, C. A., Line, J., Berrang, M. E., Meinersmann, R. J., Tillman, G. E., Wise, M. G., Siragusa, G. R., Hiett, K. L., \& Seal, B. S. (2013). The Poultry-Associated Microbiome: Network Analysis and Farm-to-Fork Characterizations. PLoS ONE, 8(2), e57190. https://doi.org/10.1371/journal.pone.0057190

Palii, A. P., Pylypenko, S. H., Lukyanov, I. M., Zub, O. V., Dombrovska, A. V., Zagumenna, K. V., Kovalchuk, Y. O., Ihnatieva, T. M., Ishchenko, K. V., Paliy, A. P., \& Orobchenko, O. L. (2019). Research of techniques of microclimate improvement in poultry houses. Ukrainian Journal of Ecology, 9(3), 41-51.

Paliy, A. P., Mashkey, A. M., Sumakova, N. V., \& Paliy, A. P. (2018d). Distribution of poultry ectoparasites in industrial farms, farms, and private plots with different rearing technologies. Biosystems Diversity, 26(2), 153-159. https://doi.org/10.15421/011824

Paliy, A. P., Rodionova, K. O., Braginec, M. V., Paliy, A. P., \& Nalivayko, L. I. (2018c). Sanitary-hygienic evaluation of meat processing enterprises productions and their sanation. Ukrainian Journal of Ecology, 8(2), 81-88. doi: https://doi.org/10.15421/2018_313

Paliy, A. P., Sumakova, N. V., Mashkey, A. M., Petrov, R. V., Paliy, A. P., \& Ishchenko, K. V. (2018a). Contamination of animalkeeping premises with eggs of parasitic worms. Biosystems Diversity, 26(4), 327-333. https://doi.org/10.15421/011848

Paliy, A. P., Sumakova, N. V., Paliy, A. P., \& Ishchenko, K. V. (2018b). Biological control of house fly. Ukrainian Journal of Ecology, 8(2), 230-234. doi: https://doi.org/10.15421/2018_332

Potter, B. D., Marcy, J. A., Owens, C. M., Slavik, M. F., Goodwin, H. L., \& Apple, J. K. (2012). Impact of performance-based sanitation systems on microbiological characteristics of poultry processing equipment and carcasses as compared with traditional sanitation systems. The Journal of Applied Poultry Research, 21(3), 669-678. https://doi.org/10.3382/japr.2011-00513

Rouger, A., Tresse, O., \& Zagorec, M. (2017). Bacterial Contaminants of Poultry Meat: Sources, Species, and Dynamics. Microorganisms, 5(3), 50. https://doi.org/10.3390/microorganisms5030050

Tan, H. Q., Li, M., Jie, D. F., Zhou, Y. F., \& Li, X. A. (2019). Effects of different litters on ammonia emissions from chicken manure. International Journal of Agricultural and Biological Engineering, 12(4), 27-33. doi: https://doi.org/10.25165/j.ijabe.20191204.5011

Waring, M. S., \& Siegel, J. A. (2011). The effect of an ion generator on indoor air quality in a residential room. Indoor Air, 21(4), 267-276. doi: https://doi.org/10.1111/j.1600-0668.2010.00696.x

Wells, J. B., Coufal, C. D., Parker, H. M., \& McDaniel, C. D. (2010). Disinfection of eggshells using ultraviolet light and hydrogen peroxide independently and in combination. Poultry Science, 89(11), 2499-2505. doi:10.3382/ps.2009-00604

Zhao, Y., Shepherd, T. A., Li, H., \& Xin, H. (2015). Environmental assessment of three egg production systems: Monitoring system and indoor air quality. Poultry Science, 94, 518-533. doi: https://doi.org/10.3382/ps/peu076

\section{Citation:}

Palii, A.P., Nanka, O.V., Kovalchuk, Y.O., Kovalchuk, A.O., Kalabska, V.S., Kholod, I.V., Pobirchenko, O.M., Umrihina, O.S., Poliakov, A.M., Ishchenko, K.V., Paliy, A.P. (2020). Effect on the bactericidal device for decontamination the air microorganisms in poultry house on the content of toxic gases. Ukrainian Journal of Ecology, 10(1), 24-29.

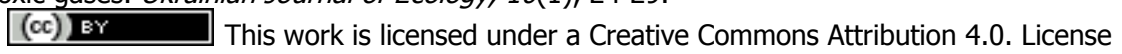

